\title{
SPECTRAL CHARACRISATION, THERMAL DECOMPOSITION AND KINETIC STUDY OF CHROMIUM (III) COMPLEXES WITH SALICYLIC ACID
}

\author{
M. K. Mishra* \\ Department of Chemistry, BIT Sindri, Dhanbad, (Jharkhand) India \\ *E-mail : mkmishrabit@gmail.com
}

\begin{abstract}
Two chromium complexes were prepared by using chromium trioxide $\left(\mathrm{CrO}_{3}\right)$ and salicylic acid. Complexes [Cr $\left.\left(\mathrm{C}_{7} \mathrm{H}_{5} \mathrm{O}_{3}\right)(\mathrm{OH})_{2}\left(\mathrm{H}_{2} \mathrm{O}\right)_{3}\right] 2 \mathrm{H}_{2} \mathrm{O}$ and $\left[\mathrm{Cr}\left(\mathrm{C}_{7} \mathrm{H}_{5} \mathrm{O}_{3}\right)_{2}(\mathrm{OH})\left(\mathrm{H}_{2} \mathrm{O}\right)_{3}\right] \mathrm{H}_{2} \mathrm{O}$ were prepared with salicylic acid. Their spectral characterization was done by using Elemental analysis $(\mathrm{C}$ and $\mathrm{H})$, Inductively coupled plasma optical emission spectroscopy (ICP - OES), Ultraviolet-visible (UV-VIS) Spectroscopy, Fourier Transform infrared (FTIR) spectroscopy, proton Nuclear Magnetic Resonance ( ${ }^{1} \mathrm{HNMR}$ ) spectroscopy and Fast Atomic Bombardment (FAB) Mass spectrometry, whereas Thermal decomposition was investigated by Differential scanning calorimetric (DSC). Kinetic parameters were obtained from DSC and the low value of activation energy of the exothermic change indicated lability of the complexes. The study includes kinetics, lability and energetic nature of the complexes prepared.
\end{abstract}

Keywords: Chromium complexes, Thermal behavior, Elemental analysis, FTIR and DSC Studies

๑ RASĀYAN. All rights reserved

\section{INTRODUCTION}

Chromium (VI) is a common and important Oxidation state of the Chromium metal and the chemistry of Chromium (VI) is marked by strong covalent bond to Oxygen and halogens. These Compounds are strong Oxidants ${ }^{1,2,3}$. Chromium trioxide is a linear polymer, which is not very soluble in most of the known hydroxylic solvent but dissolves in water, acetic anhydrite, t-butyl alcohol, pyridine etc. with accompanying depolymerization. Chromium (VI) compounds irritate the skin and mucus membrane whereas chromium (III) is an essential trace metal ion in mammalian nutrition adding in the metabolism of glucose. There is no evidence for any toxic effect of Chromium (III) ${ }^{4,5}$. Chromium (III) is the cheapest transition metal ion which can be used for catalysis ${ }^{6}$. The kinetics of chromium(III)Schiff's base and nicotinic acid complexes1, aqua(EDTA) chromium(III) complexes ${ }^{7}$, porphyrin and $\mathrm{Cr}(\mathrm{EDTA})\left(\mathrm{H}_{2} \mathrm{O}\right)$ complexes $^{8}$ and chromium (III) ethylenediamine-N,N'-diacetic acid complexes ${ }^{9}$ were studied. Chromium (III) complexes are generally inert to the ligand substitution reactions ${ }^{10}$ but reactions can be rapid under certain circumstances. Increased liability due to the presence of $\mathrm{OH}$ reported for Chromium (III) ${ }^{11,12}$. Lower enthalpy of activation for complexation reaction $\left(92 \mathrm{KJ} \mathrm{mol}^{-1}\right)$ and large negative value of $\Delta \mathrm{S}(-$ $175 \mathrm{JK}^{-1} \mathrm{~mol}^{-1}$ ) suggest the more pronounced participation of incoming ligand in the transition state and confirm the transformation of the outer sphere complex into inner sphere complex ${ }^{9}$. Thus it was thought of interesting to prepare and characterize some complexes by using $\mathrm{CrO}_{3}$ and salicylic acid. The spectral, Thermal behavior and Kinetics of these complexes have also been investigated and the results are discussed in this paper.

\section{EXPERIMENTAL}

\section{Materials}

Salicylic acid, Chromic acid $\mathrm{CrO}_{3}$ and ethyl alcohol were used as received.

\section{Preparation of Complexes}

An aqueous solution of a different molar concentration of $\mathrm{CrO}_{3}$ (dissolved in water) mixed with an ethanolic solution with a different molar concentration of salicylic acids. The resulting solution was Rasayan J. Chem., 11(4), 1393-1398(2018)

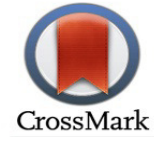


refluxed for $30 \mathrm{~min}$ after which time a suspension had formed. It was filtered and solid was washed with ethanol and dried in air. Details of the sample and their identification are summarized in Table-1.

Table-1: Details of Samples and their Identification.

\begin{tabular}{c|c|c|c|c}
\hline Sample ID & $\begin{array}{c}\mathrm{CrO}_{3}: \text { Salicylic Acid : Solvent } \\
\text { (molar ratio) }\end{array}$ & $\begin{array}{c}\text { Amount took } \\
(\mathrm{g}) \mathrm{CrO}_{3}: \mathrm{S} . \mathrm{A} .\end{array}$ & Colour & Yield \\
\hline $\mathrm{Cr} / \mathrm{H}_{2} \mathrm{Sal} \mathrm{1}$ & $\mathrm{CrO}_{3}: \mathrm{H}_{2} \mathrm{Sal}: \mathrm{H}_{2} \mathrm{O}(1: 1)$ & $1: 1.38$ & Dark brown & $0.95 \mathrm{~g}, 40 \%$ \\
\hline $\mathrm{Cr} / \mathrm{H}_{2} \mathrm{Sal} 2$ & $\mathrm{CrO}_{3}: \mathrm{H}_{2} \mathrm{Sal}: \mathrm{H}_{2} \mathrm{O}(1: 2)$ & $1: 2.76$ & Brown-black & $2.10 \mathrm{~g}, 56 \%$ \\
\hline
\end{tabular}

\section{Characterization of Samples}

Elemental analysis $(\mathrm{C} \& \mathrm{H})$ : Elemental analysis $(\mathrm{C} \& \mathrm{H})$ done at Sophisticated Analytical Instrument Facility (SAIF), Central Drug Research Institute, Lucknow, India

\section{Inductively Coupled Plasma Optical Emission Spectroscopy (ICP-OES)}

ICP-OES were recorded on Perkin Elmer 5300 DV (Dual view), diluted in acids, Plasma of Argon is the source, at Sophisticated Analytical Instrument Facility (SAIF), Indian Institute of Technology, Madras, India.

\section{UV-VIS Spectrophotometry}

UV-VIS Spectra recorded on ECIL, Hyderabad, Double beam Spectrophotometer UV5704SS, in the range 200-650nm in the Department of Applied Chemistry, Indian School of Mines , Dhanbad, India.

Fourier Transform Infrared Spectrophotometry (FTIR): The infrared spectra of solid samples were recorded in $\mathrm{KBr}$ pellets in the region $4000-400 \mathrm{~cm}^{-1}$ on Perkin Elmer spectrum-2000, Fourier Transform Infrared (FTIR) spectrometer in auto mode in the Department of Applied Chemistry, Indian School of Mines, Dhanbad, India.

\section{Proton Nuclear Magnetic Resonance ( ${ }^{1}$ HNMR) Spectrometry}

The ${ }^{1}$ HNMR spectra of complexes were recorded on Bruker DRX-300 instruments in DMSO using Tetramethylsilane (TMS) as an internal standard at Sophisticated Analytical Instrument Facility (SAIF), Central Drug Research Institute, Lucknow, India.

\section{Fast Atomic Bombardment (FAB) Mass Spectroscopy}

The FAB spectra were recorded on Jeol SX-102 (FAB) mass spectrometer instruments at Sophisticated Analytical Instrument Facility (SAIF), Central Drug Research Institute, Lucknow, India.

\section{Differential Scanning Calorimetry (DSC)}

DSC of chromium complexes was carried out on the Perkin Elmer's DSC-7 at Department of Applied Chemistry, Indian School of Mines , Dhanbad, India. In each case the following methods were used:

Sample pan: Aluminium (perforated); Scan rate: $50{ }^{\circ} \mathrm{C} / \mathrm{Min}$; Start temperature: $50^{\circ} \mathrm{C}$ End temperature: $450{ }^{\circ} \mathrm{C}$; Purge gas: Nitrogen (at the rate of $20 \mathrm{ml} / \mathrm{min}$ at the exits)

The following Perkin Elmer's DSC software was used for the purpose: Standard (Version 2.1 and 3.1); Kinetics (3.1); Auto mode (3.1); The DSC was calibrated using indium and zinc as standard.

\section{RESULTS AND DISCUSSION}

The Physical and analytical parameters of $\mathrm{Cr} / \mathrm{H}_{2}$ Sal complexes are summarized in Table- 2 and are in agreement with the proposed molecular formula for the complexes.

Table-2: Elemental Data of Complexes

\begin{tabular}{c|cc|c|c}
\hline Complexes & \multicolumn{4}{|c}{ Elemental Analysis (\%), Observed (Calculated) } \\
\hline & \multicolumn{2}{|c|}{$\mathrm{C}$} & $\mathrm{H}$ & $\mathrm{Cr}$ \\
\hline $\mathrm{Cr} / \mathrm{H}_{2} \mathrm{Sal} 1$ & 27.08 & $(26.84)$ & $5.60(5.43)$ & $17.06(16.61)$ \\
\hline $\mathrm{Cr} / \mathrm{H}_{2} \mathrm{Sal} \mathrm{2}$ & 40.98 & $(40.48)$ & $4.95(4.58)$ & $13.24(12.53)$ \\
\hline
\end{tabular}


RASĀYAN J. Chem.

Vol. 11 | No. 4 |1393 - 1398| October - December | 2018

\section{UV-VIS Spectrometry Studies}

The UV-VIS spectra of chromium complexes in DMSO are shown in Table-3 gives consolidated values of the peaks (along with absorbance) of these spectra.

Table-3: UV-VIS Spectral Data of Chromium Complexes in DMSO

\begin{tabular}{c|c|c}
\hline S. No. & Sample ID & $\lambda_{\max } \mathrm{nm}(\log \varepsilon)$ \\
\hline 01. & $\mathrm{Cr} / \mathrm{H}_{2} \mathrm{Sal} \mathrm{1}$ & $553.0(2.482), 442.5(2.400), 426.0(1.850), 447.5(1.846), 417.5(1.750)$, \\
& & $383.5(1.481), 610.5(1.452), 434.5(0.494), 406.0(0.490), 457.5(0.480)$ \\
\hline 02. & $\mathrm{Cr} / \mathrm{H}_{2} \mathrm{Sal} 2$ & $391.0(0.566), 442.5(0.562), 426.0(0.559), 447.5(0.559), 417.5(0.557)$, \\
& & $383.5(0.557), 610.5(0.557), 434.5(0.550), 406.0(0.550), 457.5(0.548)$ \\
\hline
\end{tabular}

UV-visible spectra of complexes present two bands in the ranges of 400-500 and 525-640nm which can be assigned respectively to ${ }^{4} \mathrm{~A}_{2 \mathrm{~g}} \rightarrow{ }^{4} \mathrm{~T}_{1 \mathrm{~g}}$ and ${ }^{4} \mathrm{~A}_{2 \mathrm{~g}} \rightarrow{ }^{4} \mathrm{~T}_{2 \mathrm{~g}} \mathrm{~d}-\mathrm{d}$ transitions of octahedral chromium complexes ${ }^{13}$. In the complex $\mathrm{Cr} /$ salicylic acid solutions $\left(\mathrm{Cr} / \mathrm{H}_{2} \mathrm{sal}\right)$ the bands observed at 442 and $553 \mathrm{~nm}$ of chromium in aqueous solution are characteristic of oligomeric species, probably the dimer complexes. The FTIR spectra of complexes $\mathrm{Cr} / \mathrm{H}_{2} \mathrm{Sal} 1$ and $\mathrm{Cr} / \mathrm{H}_{2} \mathrm{Sal} 2$ are shown in Figs. 1 and 2 respectively. The FTIR was taken in auto mode and peak assignments are given in Table 4.

Table-4: Peak Assignments of FTIR of Complexes ${ }^{14}$

\begin{tabular}{c|c|c|c|c|c|c}
\hline Complex & $v(\mathrm{C}=\mathrm{O})$ & $v(\mathrm{CO})$ & $v(-\mathrm{COO})$ & $v(\mathrm{CrO})$ & $v \mathrm{OH}$ & $\delta(\mathrm{OC}=\mathrm{O})+v(\mathrm{Cr}-\mathrm{O})$ \\
\hline $\mathrm{Cr} / \mathrm{H}_{2} \mathrm{Sal} 1$ & 1603 & 1243 & 1455,1571 & 675,531 & 3401 & 843,764 \\
\hline $\mathrm{Cr} / \mathrm{H}_{2} \mathrm{Sal} 2$ & 1603 & 1246 & 1467,1535 & 674,532 & 3239 & 844,759 \\
\hline
\end{tabular}

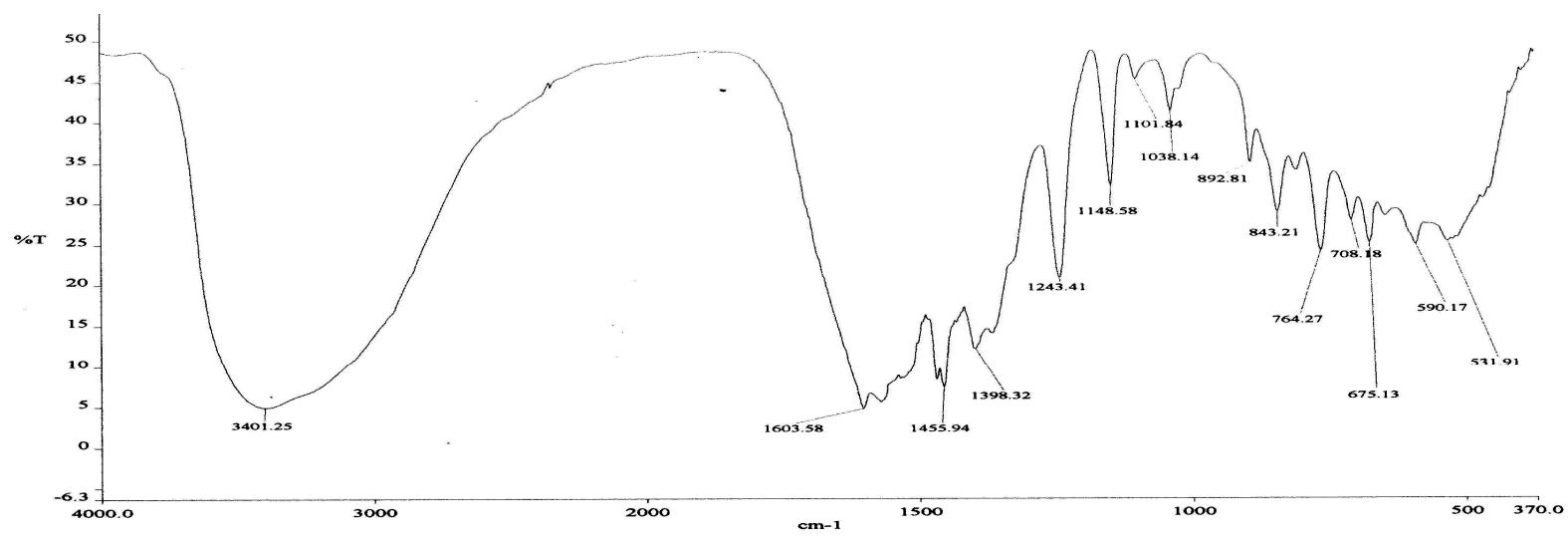

Fig.-1: FTIR Spectrum of $\mathrm{Cr} / \mathrm{H}_{2} \mathrm{Sal}$ (1)

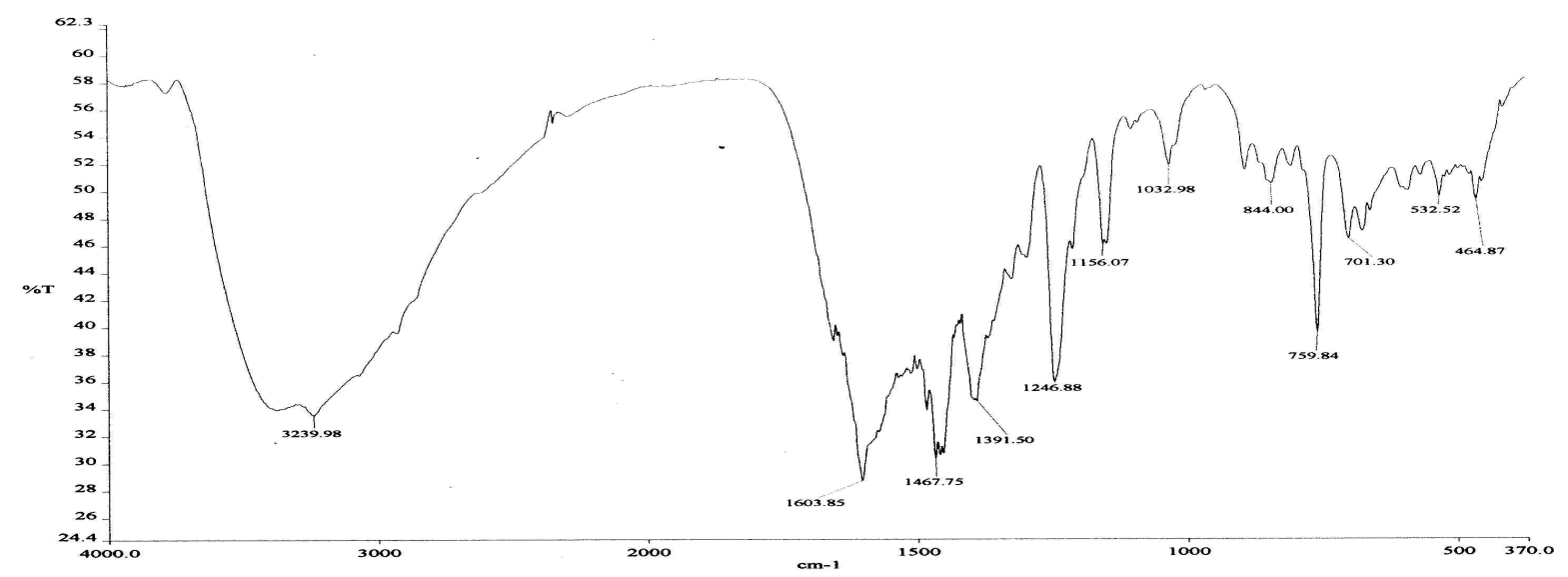

Fig.-2: FTIR Spectrum of $\mathrm{Cr} / \mathrm{H}_{2} \mathrm{Sal}$ (2) 
FTIR spectra of complexes formed indicated the presence of coordinated water molecules and orthodisubstitution in the complexes. The disappearance of the absorption bands of the salicylic acid due to O$\mathrm{H}$ of the carboxyl group in the range $3240-2594 \mathrm{~cm}^{-1}$, indicated deprotonation of the acidic group of the ligands and appearance of new bands in the region $600-700 \mathrm{~cm}^{-1}$ in the spectra of the complexes were attributed to $v(\mathrm{Cr}-0)$. Thus FTIR results suggested coordination of oxygen atom to the metal ion and indicated the formation of new complex ${ }^{15}$.

The ${ }^{1}$ HNMR spectra of complexes were recorded on Bruker DRX-300 instruments in DMSO using TMS as an internal standard. The proton resonance spectral ( ${ }^{1} \mathrm{HNMR}$ ) data of $\mathrm{Cr} / \mathrm{H}_{2} \mathrm{Sal}$ complexes are shown in Table-5.

Table-5: ${ }^{1}$ HNMR Spectral Data of Complexes and their Assignments ${ }^{16}$.

\begin{tabular}{l|l}
\hline Complexes & \multicolumn{1}{|c}{ Assignments $(\delta)$} \\
\hline $\mathrm{Cr} / \mathrm{H}_{2} \mathrm{Sal} 1$ & $8-9(4 \mathrm{H}, \mathrm{ArH}), 3.46-3.26(-\mathrm{OH}, \mathrm{Ar}), 2.56-2.44($ Protio solvent Component), 1.23 (-OH) \\
\hline $\mathrm{Cr} / \mathrm{H}_{2} \mathrm{Sal} 2$ & $\begin{array}{l}7.76-7.48(4 \mathrm{H}, \mathrm{ArH}), 6.91(4 \mathrm{H}, \mathrm{ArH}), 3.55(-\mathrm{OH}, \mathrm{Ar}) 2.72-2.27 \text { (Protio solvent } \\
\text { component) } 1.23(-\mathrm{OH}) .)\end{array}$ \\
\hline
\end{tabular}

The FAB Mass spectra, recorded on Jeol SX - 102 (FAB) Mass spectrometer instruments, of complexes $\mathrm{Cr} / \mathrm{H}_{2} \mathrm{Sal}$ and their expected fragmentation species, are given in Table 6-7. The results from FAB Mass spectra were inferred on the basis as followed by Barnwal et al ${ }^{17}$ on oxo-bridge multinuclear chromium assemblies like trinuclear complex $\left[\mathrm{Cr}_{3} \mathrm{O}(\mathrm{acac})_{3}\left(\mathrm{OCCC}_{15} \mathrm{H}_{31}\right)_{3}\right]$.

$\mathrm{Cr} / \mathrm{H}_{2} \mathrm{Sal} 1\left[\mathrm{Cr}\left(\mathrm{C}_{7} \mathrm{H}_{5} \mathrm{O}_{3}\right)(\mathrm{OH})_{2}\left(\mathrm{H}_{2} \mathrm{O}\right)_{3}\right] 2 \mathrm{H}_{2} \mathrm{O}$ Anal: found $\mathrm{C}$, 27.08; H, 5.60; Cr, 17.06 Calcd. For $\mathrm{C}_{7}$ $\mathrm{H}_{17} \mathrm{Cr} \mathrm{O}_{10}$ : C, 26.84; H, 5.43; Cr, 16.61 Calculated molecular wt. of the complex : 313; Observed molecular ion peak : 307 . The difference in molecular weight may correspond to the loss of half-molecule of water.

Table-6: FAB Mass Data of Complex $\mathrm{Cr} / \mathrm{H}_{2} \mathrm{Sal}(\mathbf{1})$

\begin{tabular}{c|c|c}
\hline Peak Position & Expected Fragmentation Species & Calculated Mass \\
\hline 307 & $\mathrm{Cr}\left(\mathrm{C}_{7} \mathrm{H}_{5} \mathrm{O}_{3}\right)(\mathrm{OH})_{2}\left(\mathrm{H}_{2} \mathrm{O}\right)_{3} 2 \mathrm{H}_{2} \mathrm{O}$ & 313 \\
\hline 289 & $\mathrm{Cr}\left(\mathrm{C}_{7} \mathrm{H}_{6} \mathrm{O}_{3}\right)(\mathrm{OH})_{2}\left(\mathrm{H}_{2} \mathrm{O}\right)_{3} \mathrm{H}_{2} \mathrm{O}$ & 295 \\
\hline 273 & $\mathrm{Cr}_{7}\left(\mathrm{C}_{7} \mathrm{H}_{5} \mathrm{O}_{3}\right)(\mathrm{OH})_{2}\left(\mathrm{H}_{2} \mathrm{O}\right)_{3}$ & 277 \\
\hline 258 & $\mathrm{Cr}\left(\mathrm{C}_{7} \mathrm{H}_{5} \mathrm{O}_{3}\right)(\mathrm{OH})_{2}\left(\mathrm{H}_{2} \mathrm{O}\right)_{2}$ & 259 \\
\hline 226 & $\mathrm{Cr}\left(\mathrm{C}_{7} \mathrm{H}_{5} \mathrm{O}_{3}\right)(\mathrm{OH})_{2}$ & 223 \\
\hline 209 & $\mathrm{Cr}\left(\mathrm{C}_{7} \mathrm{H}_{5} \mathrm{O}_{3}\right)(\mathrm{OH})$ & 206 \\
\hline 154 & $\left(\mathrm{C}_{7} \mathrm{H}_{5} \mathrm{O}_{3}\right)(\mathrm{OH})$ & 154 \\
\hline 137 & $\mathrm{C}_{7} \mathrm{H}_{5} \mathrm{O}_{3}$ & 137 \\
\hline
\end{tabular}

$\mathrm{Cr} / \mathrm{H}_{2} \mathrm{Sal} 2\left[\mathrm{Cr}\left(\mathrm{C}_{7} \mathrm{H}_{5} \mathrm{O}_{3}\right)_{2}(\mathrm{OH})\left(\mathrm{H}_{2} \mathrm{O}\right)_{3}\right] \mathrm{H}_{2} \mathrm{O}$ Anal: found $\mathrm{C}$, 40.98; H, 4.95; Cr, 13.24 Calcd. For $\mathrm{C}_{14}$ $\mathrm{H}_{19} \mathrm{Cr} \mathrm{O}_{11}: \mathrm{C}, 40.48 ; \mathrm{H}, 4.58 ; \mathrm{Cr}, 12.53$. Calculated mol. wt. of the complex: 415; Observed molecular ion peak $(\mathrm{m} / \mathrm{z}): 422$ The difference in molecular weight may correspond to the associated half-molecule of water.

Table-7: FAB Mass Data of Complex $\mathrm{Cr} / \mathrm{H}_{2} \mathrm{Sal}$ (2)

\begin{tabular}{c|c|c}
\hline Peak Position & Expected Fragmentation Species & Calculated Mass \\
\hline 422 & $\mathrm{Cr}\left(\mathrm{C}_{7} \mathrm{H}_{5} \mathrm{O}_{3}\right)(\mathrm{OH})\left(\mathrm{H}_{2} \mathrm{O}\right)_{3} \mathrm{H}_{2} \mathrm{O}$ & 415 \\
\hline 403 & $\mathrm{Cr}\left(\mathrm{C}_{7} \mathrm{H}_{5} \mathrm{O}_{3}\right)(\mathrm{OH})\left(\mathrm{H}_{2} \mathrm{O}\right)_{3}$ & 397 \\
\hline 377 & $\mathrm{Cr}\left(\mathrm{C}_{7} \mathrm{H}_{5} \mathrm{O}_{3}\right)(\mathrm{OH})\left(\mathrm{H}_{2} \mathrm{O}\right)_{2}$ & 379 \\
\hline 360 & $\mathrm{Cr}\left(\mathrm{C}_{7} \mathrm{H}_{5} \mathrm{O}_{3}\right)(\mathrm{OH})\left(\mathrm{H}_{2} \mathrm{O}\right)$ & 361 \\
\hline 344 & $\mathrm{Cr}\left(\mathrm{C}_{7} \mathrm{H}_{5} \mathrm{O}_{3}\right)(\mathrm{OH})$ & 343 \\
\hline 326 & $\mathrm{Cr}\left(\mathrm{C}_{7} \mathrm{H}_{5} \mathrm{O}_{3}\right)_{2}$ & 326 \\
\hline 189 & $\mathrm{Cr}_{7}\left(\mathrm{C}_{7} \mathrm{H}_{5} \mathrm{O}_{3}\right)$ & 189 \\
\hline 137 & $\mathrm{C}_{7} \mathrm{H}_{5} \mathrm{O}_{3}$ & 137 \\
\hline
\end{tabular}

\section{Thermal Decomposition Studies on $\mathrm{Cr} / \mathrm{H}_{2} \mathrm{Sal}$ Complexes}

DSC of $\mathrm{Cr} / \mathrm{H}_{2} \mathrm{Sal}$ complexes was carried out on the Perkin Elmer's DSC - 7 and thermograms are shown in Figs. -3 to 6 respectively. Their kinetic parameters are given in Table-8. 
RASĀYAN J. Chem.

Vol. 11 | No. 4 |1393 - 1398| October - December | 2018

Table-8: Kinetic Parameters of Complexes Obtained From DSC Thermogram.

\begin{tabular}{c|c|c|c|c|c|c}
\hline Sample Code & $\begin{array}{c}\text { Temp. Range } \\
\left({ }^{0} \mathrm{C}\right)\end{array}$ & $\begin{array}{c}\text { Peak Temp. } \\
\left({ }^{0} \mathrm{C}\right)\end{array}$ & Inko & $\begin{array}{c}\text { Change in } \\
\text { Enthalpy, } \\
\Delta \mathrm{H}(\mathrm{J} / \mathrm{g})\end{array}$ & $\begin{array}{c}\text { Activation } \\
\text { Energy } \\
(\mathrm{KJ} / \mathrm{mol})\end{array}$ & $\begin{array}{c}\text { Order of } \\
\text { Reaction }\end{array}$ \\
\hline $\mathrm{Cr} / \mathrm{H}_{2} \mathrm{Sal} 1$ A & $70.68-169.11$ & 120.03 & $20.93 \pm 0.45$ & 203.32 & $80.57 \pm 1.74$ & $1.37 \pm 0.02$ \\
$\mathrm{Cr} / \mathrm{H}_{2} \mathrm{Sal1}$ B & $240.16-359.29$ & 309.71 & $8.56 \pm 0.18$ & -42.76 & $62.89 \pm 1.35$ & $0.71 \pm 0.01$ \\
\hline $\mathrm{Cr} / \mathrm{H}_{2} \mathrm{Sal} 2 \mathrm{~A}$ & $64.77-177$ & 162.55 & $4.01 \pm 0.08$ & 152.51 & $28.24 \pm 0.61$ & $0.63 \pm 0.01$ \\
$\mathrm{Cr} / \mathrm{H}_{2} \mathrm{Sal} 2 \mathrm{~B}$ & $235.25-423.48$ & 307.25 & $3.7 \pm 0.8$ & -229.25 & $42.41 \pm 0.91$ & $0.89 \pm 0.01$ \\
\hline
\end{tabular}

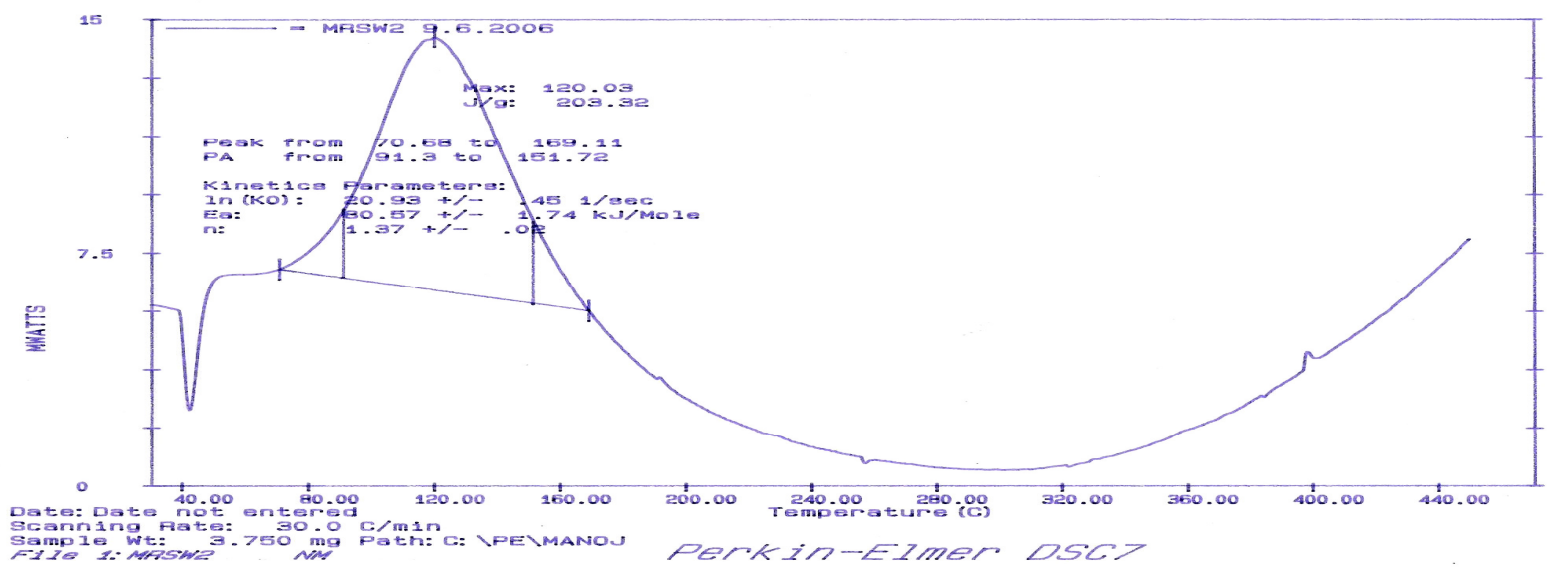

Fig.-3: DSC Thermogram of $\mathrm{Cr} / \mathrm{H}_{2} \mathrm{Sal} 1 \mathrm{~A}$

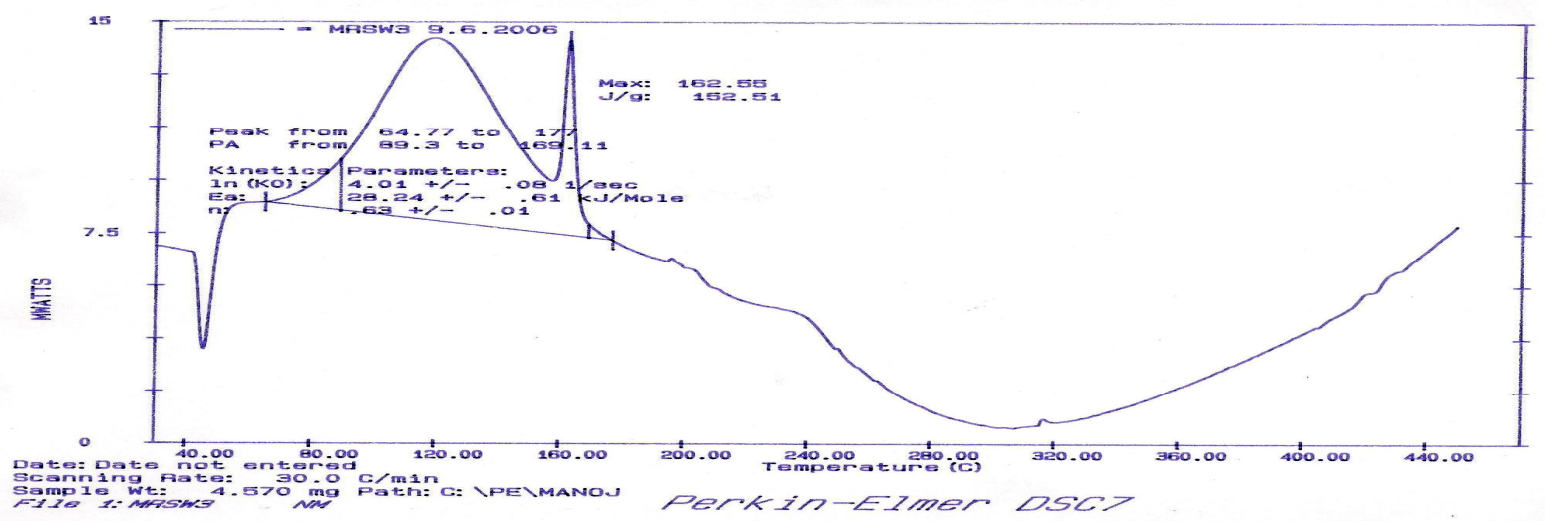

Fig.-4: DSC Thermogram of $\mathrm{Cr} / \mathrm{H}_{2} \mathrm{Sal} 1 \mathrm{~B}$

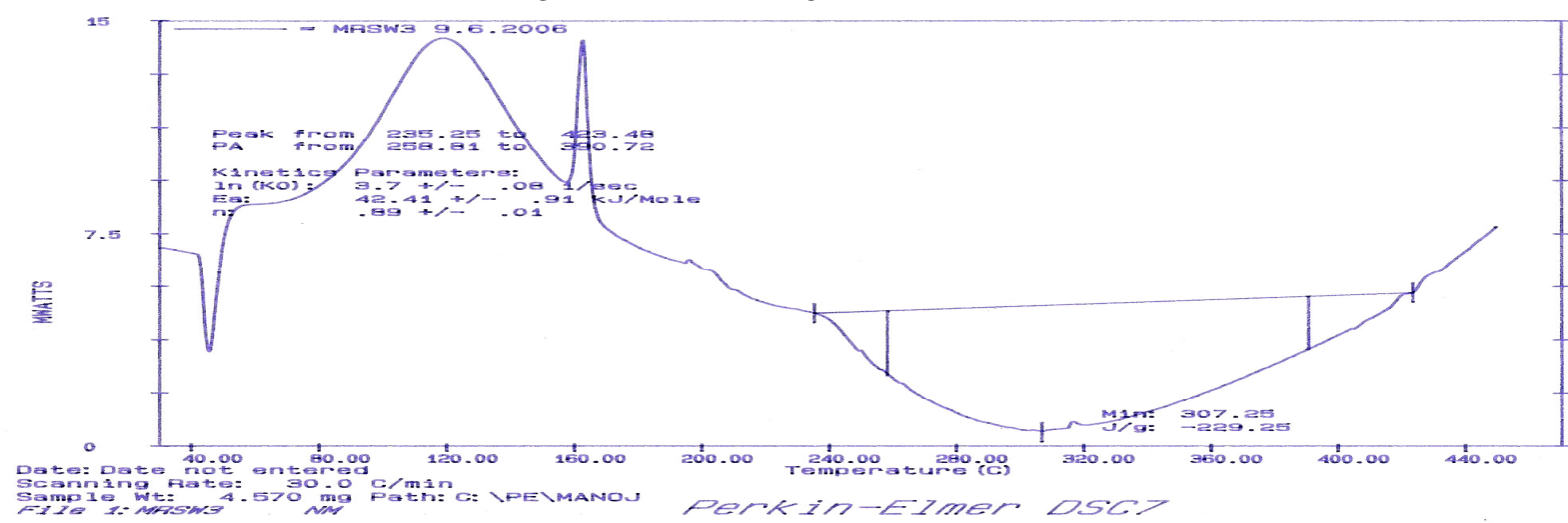

Fig.-5: DSC Thermogram of $\mathrm{Cr} / \mathrm{H}_{2} \mathrm{Sal} 2 \mathrm{~A}$ 
RASĀYAN J. Chem.

Vol. 11 | No. 4 |1393 - 1398| October - December | 2018

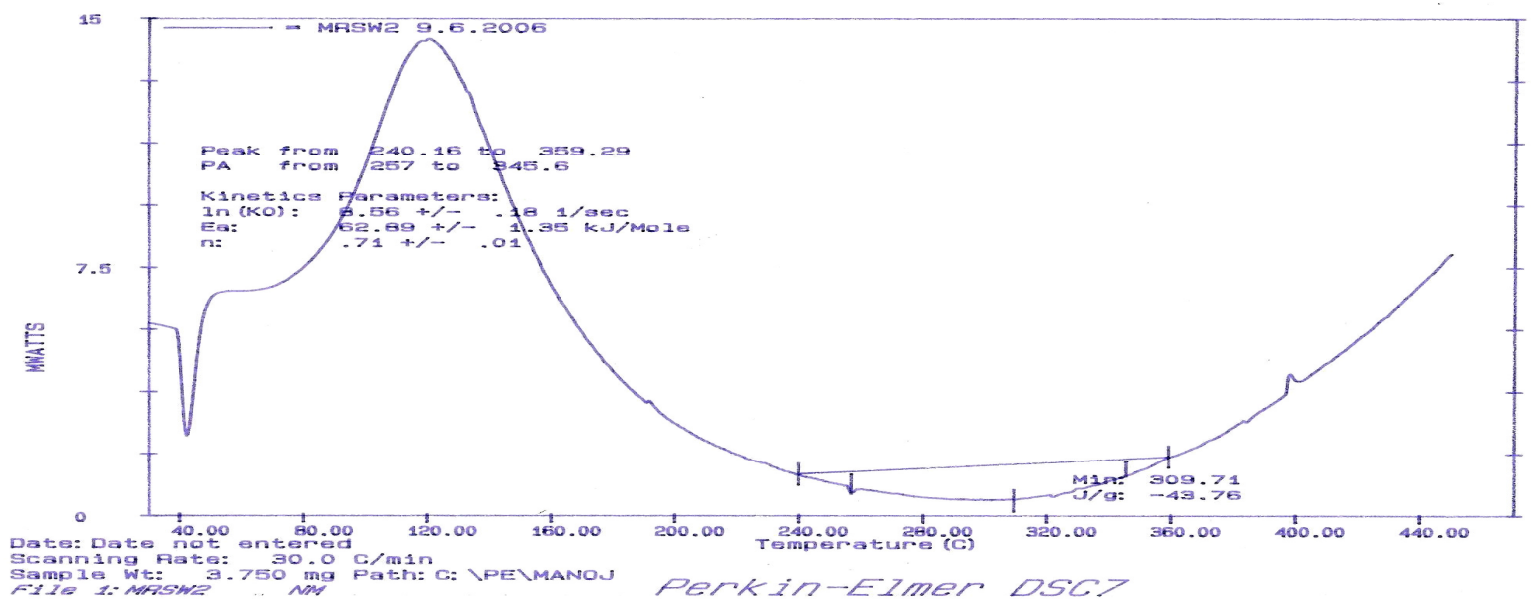

Fig.-6: DSC Thermogram of $\mathrm{Cr} / \mathrm{H}_{2} \mathrm{Sal} 2 \mathrm{~B}$

The kinetic parameters: enthalpy $(\Delta \mathrm{H})$, activation energy $(\mathrm{Ea}), \ln \mathrm{K}_{0}$, the order of reaction $(\mathrm{n})$ and a peak temperature of the $\mathrm{Cr}$ / Salicylic acid complexes were determined from DSC thermogram. Generally, second step decomposition was noticed to be an exothermic process and heat flow takes place at 167.36, $309.71,307.25,274.8,295.75,291.05$ and $303.45^{\circ} \mathrm{C}$ and showed a low value of activation energy, indicating lability of the complexes. The decomposition follows the first order of reaction. The complexes showed an endothermic peak between 84.9 to $162.55^{\circ} \mathrm{C}$ for dehydration process ${ }^{18}$. The final step change of $\mathrm{Cr} / \mathrm{H}_{2}$ sal complexes (monomeric, dimeric in nature) could not be recorded as scanning was done up to $450^{\circ} \mathrm{C}$.

\section{CONCLUSION}

Two chromium complexes were prepared by using chromium trioxide $\left(\mathrm{CrO}_{3}\right)$ and salicylic acid. Complexes $\left[\mathrm{Cr}\left(\mathrm{C}_{7} \mathrm{H}_{5} \mathrm{O}_{3}\right)(\mathrm{OH})_{2}\left(\mathrm{H}_{2} \mathrm{O}\right)_{3}\right] 2 \mathrm{H}_{2} \mathrm{O}$ and $\left[\mathrm{Cr}\left(\mathrm{C}_{7} \mathrm{H}_{5} \mathrm{O}_{3}\right)_{2}(\mathrm{OH})\left(\mathrm{H}_{2} \mathrm{O}\right)_{3}\right] \mathrm{H}_{2} \mathrm{O}$ were prepared with salicylic acid. The low value of activation energy of the exothermic change indicated the lability of the complexes. Thus the kinetics and lability of the complexes could be predicted from the DSC.

\section{REFERENCES}

1. J. T. Lin, G. P. Hagen, and J. E. Ellis, Organometallic, 3 , 1288 (1984)

2. A. Bakac and J. H. Espenson, Inorg. Chem. , 31,1108 (1992)

3. G. Wilkinson, Polyhedron, 12, 363(1993)

4. E. O. Fischer, Angew. Chem., 85,618(1973)

5. F. Basolo, Mechanisms of Inorganic Reactions, 2, (1967)

6. M. W. Rophael, Chem. Scr., 20,171 (1982)

7. Larry E. Gerdom, Norman A. Baenziger and Harold M. Goff, Inorg.,Chem., 20,1606(1981)

8. T. B. Yormah, D. V. A. Fode and M. K. Kormoh, AJST, 3(1), 108(2002)

9. Samy S. Anis, Materials Chemistry and Physics, 72, 88(2001)

10. J. O. Edwards, Inorg. Chim. Acta., 11, 47(1974)

11. T. Ramasami, R. K. Wharton and A. G. Sykes, Inorg. Chem., 14,359(1975)

12. C. R. Krishnamoorthy and G. M. Harris, J.Coord.Chem.,10,55(1980)

13. D. Vasovic and Dj. Stojakovic, J.Coord.Chem.,17,325(1988)

14. D. J. Hewkin and W. P. Griffith, J.Chem Soc., A, 472 (1966)

15. L. J. Bellamy, The Infrared Spectrum of complex molecules, Third ed., Chapman and Hall Ltd London, 1975

16. C. L. Broadhurst, W. F. Schmidt, J. B. Reeves, M. M. Polansky, K. Gautschi and R. A. Anderson, J. Inorg. BIochem., 66, 119(1997)

17. B. P. Barnwal and Talat Fatma, Journal of Molecular Structure, 750,75(2005)

18. N. Deb, S. D. Baruah and N. N. Dass, Thermochim. Acta., 285,301(1996)

[RJC-3056/2018] 